\title{
Serum Procalcitonin Levels in Patients with Acute Central Nervous System Infections
}

\author{
Yordan Kalchev ${ }^{1,2 \star}$, Tsetsa Petkova ${ }^{3}$, Ralitsa Raycheva ${ }^{4}$, Bothwell Kabayira ${ }^{5}$, Tanya Deneva ${ }^{6,7}$, Marianna Murdjeva ${ }^{1,2,3,8}$ \\ ${ }^{1}$ Department of Microbiology and Immunology, Faculty of Pharmacy, Medical University, Plovdiv, Bulgaria; ${ }^{2}$ Laboratory \\ of Microbiology, St. George University Hospital, Plovdiv, Bulgaria; ${ }^{3}$ Laboratory of Virology, St. George University Hospital, \\ Plovdiv, Bulgaria; ${ }^{4}$ Department of Social Medicine and Public Health, Faculty of Public Health, Medical University, Plovdiv, \\ Bulgaria; ${ }^{5}$ Medical student, Faculty of Medicine, Medical University, Plovdiv, Bulgaria; ${ }^{6}$ Clinical Laboratory Department, Faculty \\ of Medicine, Medical University, Plovdiv, Bulgaria; ${ }^{7}$ Clinical Laboratory, St. George University Hospital, Plovdiv, Bulgaria; \\ ${ }^{8}$ Research Institute, Medical University, Plovdiv, Bulgaria
}

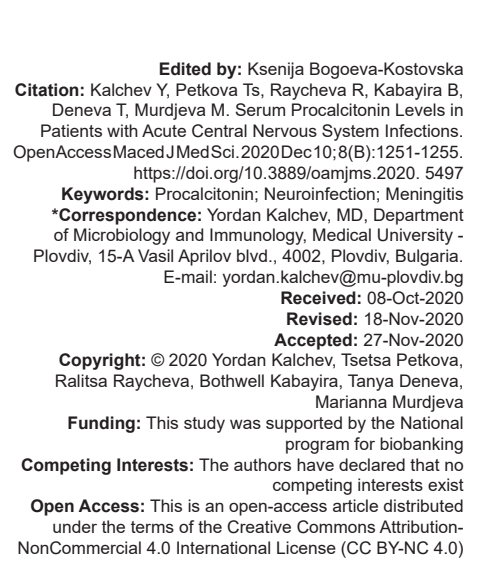

\section{Introduction}

Central nervous system (CNS) infections are medical emergencies having diverse etiology with viruses and bacteria being the most common pathogens [1]. Bacterial infections are associated with high mortality and neurological sequelae, whereas viral diseases are in most cases self-limiting and have a good prognosis [2]. The clinical findings are poor discriminator of the etiology so it could sometimes be difficult to distinguish between bacterial and aseptic meningitis in patients presenting with an acute CNS infection [3]. The gold standard for laboratory evaluation includes cerebrospinal fluid (CSF) analysis of cell count, glucose, and protein levels along with serum C-reactive protein (CRP) [4]. There are many recommendations to initiate antibiotic therapy as soon as possible until culture results are available within the next $24-78 \mathrm{~h}$, giving the fact that the mortality rate is increasing with any delay of antibiotic administration if a bacterial infection of the brain is present [5], [6]. For these various reasons, a fast and easy-to-perform biomarker test is needed to improve the management of such patients, aiding the decision about the start of the antibiotic treatment. Giving the heterogeneous results reported in various scientific researches, the validation of this biomarker in the management of patients with acute neuroinfections is still challenging. Because procalcitonin (PCT) testing has already been implemented in many laboratories for evaluating septic patients and it is an easily accessible biomarker, we aimed to examine its role specifically in discriminating acute bacterial from viral infections of the CNS.

\section{Materials and Methods}

This prospective study included 80 patients with both clinical symptoms and laboratory findings of an 
acute CNS infection, admitted to "St. George" University Hospital - Plovdiv. Patients presented with fever, signs of meningeal irritation, altered consciousness, and abnormal CSF - pleocytosis, elevated protein, and decreased or normal glucose levels. A paired sample of serum and CSF was collected through lumbar puncture and venipuncture, using an aseptic technique.

Following the algorithm, the CSF analysis included cell count, protein, and glucose levels, as well as microbiological examination to determine the etiology. CRP and PCT levels were detected in the patient's sera. PCT levels were measured by enzyme-linked fluorescent assay technology (Vidas, BioMerieux). Values below the detection threshold of $0.05 \mathrm{ng} / \mathrm{ml}$ were considered as zeroes. Serum CRP levels were examined by an immunoturbidimetric method applied on a Beckman Coulter AU analyzer (System). Routine methods such as direct microscopy and culturing were used for microbiological analysis. CSF samples were also subject to slide-agglutination test (Pastorex, Biorad) and genetic analysis by multiplex polymerase chain reaction (PCR) (FilmArray, Biomerieux). Microscope slides stained by Gram, methylene blue, and Ziehl-Neelsen were observed using immersion oil light microscopy. Samples were cultured on a blood agar plate and Levinthal's medium incubated for $48 \mathrm{~h}$ at $36 \pm 1{ }^{\circ} \mathrm{C}$ with $5-10 \%$ of $\mathrm{CO}_{2}$ enriched atmosphere. Another set of the blood agar plate and Levinthal's medium was incubated at $36 \pm 1^{\circ} \mathrm{C}$ without further $\mathrm{CO}_{2}$ supplementation along with eosin-methylene blue agar for Gram-negative bacteria. Sabouraud-dextrose agar for fungi was also inoculated and kept up to 14 days.

Numeric variables are presented as median ( $25^{\text {th }}$ percentile and $75^{\text {th }}$ percentile) due to the lack of normal distribution. Categorical variables are presented as a percentage (\%). Kruskal-Wallis $\mathrm{H}$ test was applied to compare the ranked median between more than two independent groups. Logistic regression was used to generate a receiver operating characteristic (ROC) curve as an assessment of the discriminatory power of each parameter in the diagnosis of bacterial neuroinfections. A general scale for interpreting area under the curve (AUC) values classifies an AUC value of $0.90-0.99$ as excellent discrimination, a value of $0.80-0.89$ as good discrimination, a value of $0.70-0.79$ as fair discrimination, and a value of 0.51-0.69 as poor discrimination. Best cutoff values were chosen using Youden's index (highest sensitivity + specificity - 1). A two-sided $p<0.05$ was considered statistically significant. Statistical analyses were performed using SPSS Statistics v. 26 software (IBM Corp., Chicago, IL, USA).

This study was in accordance with the Bulgarian laws and the Standards for good medical practice. No patients were admitted or were subject to lumbar puncture and/or venipuncture, only for the purpose of the presented study.

\section{Results}

The basic demographic characteristics of the 80 studied patients are presented in Table 1. Following the results of the microbiological analysis, the cases were divided into three groups based on the etiology - bacterial neuroinfection (BN), viral neuroinfection (VN), and unidentified neuroinfection (UN). Bacterial CNS infection was found in $26.3 \%(n=21)$, whereas viruses were detected in $17.5 \%(n=14)$ of the patients. In the majority of the cases $(56.2 \% ; n=45)$, the etiology of the disease remained unidentified. Streptococcus pneumoniae was the predominant pathogen among bacteria in $57.1 \%(n=12)$ of the patients, followed by Staphylococcus aureus $-14.3 \%(n=3)$, Listeria monocytogenes - 9.5\% ( $n=2)$, Haemophilus influenzae $-9.5 \%(n=2)$, Neisseria meningitidis - 4.8\% ( $n=1)$, and Escherichia coli $-4.8 \%(\mathrm{n}=1)$.

Table 1: Basic demographic characteristics of the studied patients

\begin{tabular}{llll}
\hline Parameter & $\mathrm{BN}^{1}(\mathrm{n}=21)$ & $\mathrm{VN}^{2}(\mathrm{n}=14)$ & $\mathrm{UN}^{3}(\mathrm{n}=45)$ \\
\hline Age in years, median (range) & $59(1-88)$ & $4.5(0.6-60)$ & $27(0.08-77)$ \\
Males, $\mathrm{n}(\%)$ & $14(66.7)$ & $6(42.9)$ & $23(51.1)$ \\
Females, $\mathrm{n}(\%)$ & $7(33.3)$ & $8(57.1)$ & $22(48.9)$ \\
\hline 1-BN: Bacterial neuroinfection; 2-VN: Viral neuroinfection; 3-UN: Unidentified neuroinfection
\end{tabular}

Enteroviruses were the leading cause of VNs $-42.9 \%(n=6)$. We also detected HHV $6-21.4 \%$ ( $=3), \mathrm{HSV}-1-14.3 \%(\mathrm{n}=2), \mathrm{VZV}-14.3 \%(\mathrm{n}=2)$, and HSV-2 - 7.1\% ( $n=1)$.

Our data indicate that all the studied parameters in the CSF compartment (cells, glucose, and protein levels), as well as serum CRP and PCT levels, significantly differ across the observed groups. The results are presented in Table 2. The distribution of serum PCT was not the same across the studied groups ( $W=28.10 ; p=0.000)$. A statistically significant difference in the median PCT was observed between the $B N$ and $V N(W=22.55 ; p=0.004)$ as well as $B N$ and UN $(W=28.10 ; p=0.000)$. We did not find a significantly different median value between $\mathrm{VN}$ and UN $(\mathrm{W}=4.55 ; \mathrm{p}=1.000)$ - Figure 1 .

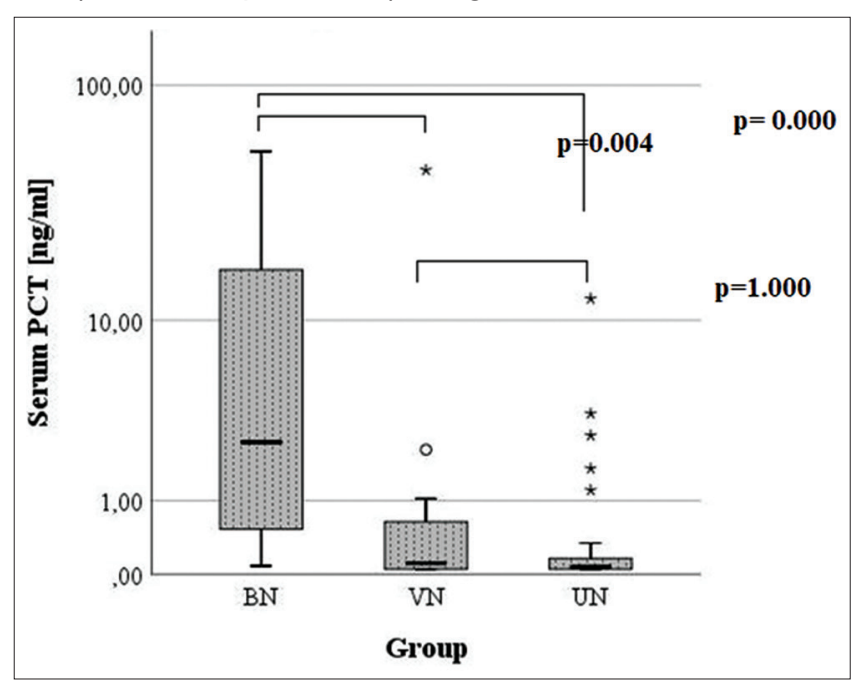

Figure 1: Comparison of the procalcitonin ranked median across the studied groups 
Table 2: Medians of the studied parameters

\begin{tabular}{|c|c|c|c|c|}
\hline Parameter & $\mathrm{BN}^{1}(\mathrm{n}=21)$ & $\operatorname{VN}^{2}(n=14)$ & $\mathrm{UN}^{3}(\mathrm{n}=32)$ & $W^{4}$ (p-value) \\
\hline $\operatorname{CSF}^{5}$ white-blood cell count $(\mathrm{WBC})^{6}\left(\times 10^{6} / \mathrm{l}\right)$ & $426(136-2560)$ & $20.5(2.75-64.75)$ & $12(3-100.5)$ & $26.54(0.000)$ \\
\hline CSF protein $(\mathrm{g} / \mathrm{l})$ & $4.36(2.28-6.49)$ & $0.41(0.28-0.79)$ & $0.81(0.49-1.36)$ & $36.65(0.000)$ \\
\hline CSF glucose (mmol/l) & $1.32(0.4-2.7)$ & $3.92(3.71-4.75)$ & $3.8(3.15-4.7)$ & $25.01(0.000)$ \\
\hline CSF/serum glucose ratio & $0.17(0.06-0.37)$ & $0.78(0.67-0.93)$ & $0.63(0.46-0.78)$ & $31.32(0.000)$ \\
\hline Serum $\mathrm{CRP}^{7}(\mathrm{mg} / \mathrm{l})$ & $237(135-308)$ & $11(3-32)$ & $11(1.84-49)$ & $27.96(0.000)$ \\
\hline Serum $\mathrm{PCT}^{8}(\mathrm{ng} / \mathrm{ml})$ & $2.47(0.53-17.06)$ & $0.11(0.05-0.84)$ & $0.07(0.05-0.16)$ & $25.17(0.000)$ \\
\hline
\end{tabular}

By measuring the AUC, we found excellent discriminatory power (AUC >0.9) for CSF protein content, glucose level, CSF/serum glucose ratio, and serum CRP. The AUC for CSF WBC count and serum PCT was 0.859 and 0.823 , respectively. All the results were statistically significant. Data are presented in Table 3.

Table 3: Estimated AUC for the studied parameters and combination of parameters

\begin{tabular}{lllll}
\hline Parameter & $\mathrm{AUC}^{1}$ & $\mathrm{SE}^{2}$ & $\mathrm{p}^{3}$ & $95 \% \mathrm{Cl}^{4}$ \\
\hline CSF $^{5}$ WBC $^{6}$ & 0.859 & 0.072 & 0.001 & $0.718-1.000$ \\
CSF protein & 0.965 & 0.033 & 0.000 & $0.900-1.000$ \\
CSF glucose & 0.901 & 0.058 & 0.000 & $0.788-1.000$ \\
CSF/serum glucose ratio & 0.922 & 0.052 & 0.000 & $0.820-1.000$ \\
Serum CRP & 0.939 & 0.051 & 0.000 & $0.840-1.000$ \\
Serum PCT & 0.823 & 0.091 & 0.004 & $0.645-1.000$ \\
Serum PCT + CSF WBC & 0.869 & 0.069 & 0.001 & $0.733-1.000$ \\
Serum PCT + CSF Protein & 0.914 & 0.082 & 0.000 & $0.754-1.000$ \\
Serum PCT + CSF Glucose & 0.888 & 0.084 & 0.001 & $0.724-1.000$ \\
Serum PCT + CSF Glucose ratio & 0.920 & 0.077 & 0.000 & $0.769-1.000$ \\
Serum PCT + Serum CRP & 0.929 & 0.053 & 0.000 & $0.826-1.000$ \\
\hline AUC: Area under the curve; 1-ROC: Receiver operating characteristic curve; 2-SE: Standard error; \\
3-: Significance level; 4-Cl: Confidence interval; 5-CSF: Cerebrospinal fluid; 6-WBC: White-blood cell count; \\
7-CRP: C-reactive protein; 8-PCT: procalcitonin.
\end{tabular}

When combining PCT with other parameters, the AUC is slightly increased, with the largest area observed when combining serum PCT and serum CRP. The corresponding ROC curves are shown in Figure 2.

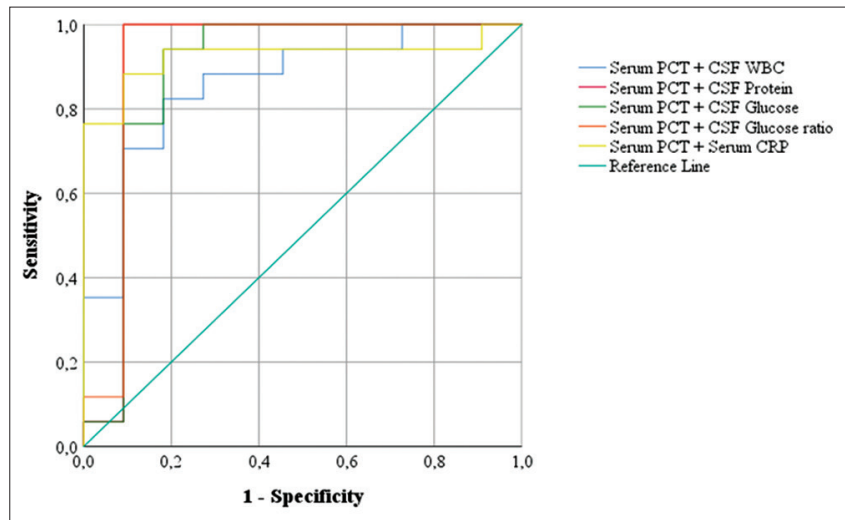

Figure 2: Receiver operating characteristic curves when combining serum procalcitonin with other parameters

\section{Discussion}

PCT is a precursor protein produced mainly by the $\mathrm{C}$-cells of the thyroid gland that is further cleaved into calcitonin, which is involved in calcium homeostasis. Bacterial pathogens can upregulate the CALC-1 gene expression by their antigens or indirectly by inducing the production of interleukin 6 (IL-6) and IL-1 [7]. In addition, many different extra-thyroid tissues can also produce this protein when stimulated by bacterial antigens or the cytokines secreted after macrophage activation. These lack the ability to cleave the PCT into calcitonin, thus leading to a rapid increase in PCT levels in the serum [7], [8]. Pure viral infections do not lead to a sufficient increase in PCT levels due to a decrease in tumor necrosis factor- $\alpha$, which is essential for its production and viral interferons- $\gamma$ suppresses the PCT expression [8], [9]. Local bacterial colonization or infection does not cause an increase above the detection limit but is secreted into circulation during severe systematic bacterial infection [10]. Described back in 1993 as a marker of sepsis; nowadays, this molecule is included in different antibiotic stewardship algorithms for initiation and discontinuation of antimicrobial therapy, aiming to reduce the excessive antibiotic consumption [11], [12], [13]. PCT production could also be initiated by various non-infectious causes such as autoimmune disorders, after liver transplantation, rhabdomyolysis, and heat shock [10]. Lower respiratory tract diseases and pleural diseases can also be associated with an increase in serum PCT [10], [14], [15]. Following the first publication on PCT measurement in patients with meningitis and bacterial meningitis in 1997, numerous studies are still evaluation the role of this biomarker for differentiation of bacterial from viral infections but unfortunately with diverse results [16].

Schwarz et al. also reported the same tendency we observed in our study, that the serum PCT and CRP, WBC count, protein, and glucose content are significantly higher in those with $\mathrm{BN}$ when compared to non-bacterial infection of the brain [17]. We similarly conclude that the glucose ratio significantly differs between these groups, which are in contrast to the cited research.

The reported median value of serum PCT by Jereb et al. in the patients with bacterial CNS infections was higher $(6.45 \mathrm{ng} / \mathrm{ml} ; 0.25-43.76 \mathrm{ng} / \mathrm{ml})$ than the median, we observed for these patients $-2.47 \mathrm{ng} / \mathrm{ml}$; $0.05-17.06 \mathrm{ng} / \mathrm{ml}$ [18]. Similarly, the team reported a higher median in the group of $\mathrm{VN}(0.27 \mathrm{ng} / \mathrm{ml} ; 0.05$ $0.44 \mathrm{ng} / \mathrm{ml})$ when compared to our results $(0.11 \mathrm{ng} / \mathrm{ml}$; $0.05-0.84 \mathrm{ng} / \mathrm{ml}$ ).

A systematic review by Wei et al. on PCTs role in patients with acute bacterial meningitis concluded that both serum and CSF PCT levels were effective in differentiating patients with acute bacterial meningitis, 
with the serum PCT having superior diagnostic potential when compared to the CSF. Even more, the serum PCT alone was a sufficient biomarker to indicate or rule out bacterial meningitis but not so for the CSF PCT [19]. The extensive use of microbiological methods to identify the causative agent in our study resulted in not having a sufficient volume of the CSF specimens to be tested for PCT.

According to the study on 50 patients with meningitis, the serum CRP AUC (0.889) was greater than the serum PCT AUC (0.608) [20]. Although the reported AUC of serum $\mathrm{PCT}$ in our study is larger (0.823), we also found that serum CRP is superior to serum PCT in a patient with acute infection of the CNS. The reported by the team best cutoff value of serum PCT is $0.6 \mathrm{ng} / \mathrm{ml}$. On the other hand, a different study concludes that CRP is inferior to serum PCT and CSF protein content [21]. Alkholi et al. concluded in their paper that serum PCT has a better diagnostic in comparison with CRP and leukocyte count. Our data suggest that serum PCT is neither superior to CRP or WBC count [22].

The best cutoff level of serum PCT that we determined is $0.25 \mathrm{ng} / \mathrm{ml}$ (sensitivity $83.3 \%$ and specificity $72.7 \%$ ). Although we calculated lower sensitivity and specificity at this particular cutoff, the value is quite similar to some other studies. Viallon et al. published in two separate papers, reported the best cutoff of $0.20 \mathrm{ng} / \mathrm{ml}$ (sensitivity of 95 , and a specificity of $100 \%$ ), and $0.28 \mathrm{ng} / \mathrm{ml}$ (sensitivity $95 \%$ and specificity $100 \%)$, respectively [21], [23].

When combining PCT with other parameters, the AUC is slightly increased. The best increase of the AUC is observed when matching serum PCT and serum CRP. According to a study by Markéta et al., this combination offers the best sensitivity and specificity, regardless of focusing on the fungal infection [24]. The team reported that the combination of high CRP with low PCT could be suggestive for fungal infections in immunocompromised hosts of the brain. We assume that the high serum PCT and CRP levels could be pointing toward a $\mathrm{BN}$.

In the patient who experienced $E$. coli $\mathrm{K} 1$ meningitis, we determined relatively low serum PCT levels for bacterial infection $-0.08 \mathrm{ng} / \mathrm{ml}$. The patient did not receive any antibiotics before the lumbar puncture and was tested positive for the bacterium on the direct microscopy, culturing, latex-agglutination test, and multiplex PCR. Contamination of the sample could be excluded due to the clinical picture, the severe onset, and the abnormal CSF parameters, suggesting $B N$. Given the fact that, ventriculoperitoneal shunt was placed before the onset of infection, the final diagnosis of shunt-associated neuroinfection was established. The bacterium had never appeared in the blood, which was confirmed by several negative blood cultures, but introduced directly into the CNS through the shunt. These findings could explain the relatively low serum PCT, which seems to be quite sensitive to the presence of bacterial pathogens in the bloodstream itself. Although the hematogenous spread is the most common mechanism of invasion to the CNS, it is reasonable to assume that if a particular bacterium is not found in the blood before reaching the CNS, lower serum PCT might be observed, thus limiting the application of this biomarker in such patients.

On the other hand, an HSV-1 PCR-positive patient had serum PCT levels of $44.39 \mathrm{ng} / \mathrm{ml}$. We were not able to recover any bacteria. This could be probably explained to some extent by the acute necrotizing encephalopathy observed in the patient, not only confirming the etiology but also pointing to other mechanisms, like necrosis, that might lead to an increase in PCT in the serum.

\section{Study limitations}

However, some limitations should be noted. First, a limitation of our study is the relatively small number of patients in the groups we compare. Several methods were used simultaneously for microbiological diagnosis to increase the detection rate and recognize the etiology of the neuroinfection. Unfortunately, the majority of the cases remained unidentified, although the findings were consistent with a viral or bacterial infection of the CNS. Second, specimen collection was not standardized with respect to the onset of the disease. They were obtained as soon as possible when patients were presenting with symptoms but the actual time from one patient to another may vary, thus not evaluating the effect of the serum PCT's kinetic properties, which might influence the discriminatory power of the biomarker.

\section{Conclusion}

In summary, serum PCT levels are significantly higher in patients with acute bacterial infections of the brain and could differentiate between bacterial and nonBNs. We conclude that as a stand-alone biomarker, its discriminatory power is not superior to the classical laboratory parameters in the CSF and serum CRP. The best cutoff value of serum PCT that we calculated is $0.25 \mathrm{ng} / \mathrm{ml}$ (sensitivity $=83.3 \%$ and specificity $=$ $72.7 \%$ ). The PCT's discriminatory potential can be best increased when combining with serum CRP.

\section{References}

1. Nigrovic LE, Kuppermann N, Macias CG, Cannavino CR, Moro-Sutherland DM, Schremmer RD, et al. Clinical prediction 
rule for identifying children with cerebrospinal fluid pleocytosis at very low risk of bacterial meningitis. J Am Med Assoc. 2007;297(1):52-60. https://doi.org/10.1001/jama.297.1.52 PMid: 17200475

2. Sáez-Llorens $X, M c C r a c k e n ~ G H$. Bacterial meningitis in children Lancet. 2003;361(9375):2139-48. https://doi.org/10.1016/ s0140-6736(03)13693-8

PMid:12826449

3. Lucht F. Sensibilité et spécificité des signes cliniques chez l'adulte [Sensitivity and specificity of clinical signs in adults]. Med Mal Infect. 2009;39(7-8):445-51.

4. Dubos F, Korczowski B, Aygun DA, Martinot A, Prat C, GalettoLacour A, et al. Serum procalcitonin level and other biological markers to distinguish between bacterial and aseptic meningitis in children: A European multicenter case cohort study. Arch Pediatr Adolesc Med. 2008;162(12):1157-63. https://doi. org/10.1001/archpedi.162.12.1157

PMid: 19047543

5. Feigin RD, McCracken GH, Klein JO. Diagnosis and management of meningitis. Pediatr Infect Dis J. 1992;11(9):785-814.

PMid:1448332

6. Tunkel AR, Hartman BJ, Kaplan SL, Kaufman BA, Roos KL, Scheld WM, et al. Practice guidelines for the management of bacterial meningitis. Clin Infect Dis. 2004;39(9):1267-84. https:// doi.org/10.1086/425368

PMid: 15494903

7. Binnie A, Lage J, Dos Santos CC. How can biomarkers be used to differentiate between infection and non-infectious causes of inflammation? Evid Based Pract Crit Care. 2020;2020:319-24. https://doi.org/10.1016/b978-0-323-64068-8.00055-9

8. Gilbert DN. Use of plasma procalcitonin levels as an adjunct to clinical microbiology. J Clin Microbiol. 2010;48(7):2325-9. PMid:20421436

9. Chua AP, Lee $\mathrm{KH}$. Procalcitonin in severe acute respiratory syndrome (SARS). J Infect. 2004;48(4):303-6. PMid: 15066330

10. Meisner M. Update on procalcitonin measurements. Ann Lab Med. 2014;34(4):263-73.

PMid:24982830

11. Assicot M, Bohuon C, Gendrel D, Raymond J, Carsin H, Guilbaud J. High serum procalcitonin concentrations in patients with sepsis and infection. Lancet. 1993;341(8844):515-8. https://doi.org/10.1016/0140-6736(93)90277-n PMid:8094770

12. Choi JJ, McCarthy MW. Novel applications for serum procalcitonin testing in clinical practice. Exp Rev Mol Diagn. 2018;18(1):27-34. PMid:29148856

13. Schuetz P, Bretscher C, Bernasconi L, Mueller B. Overview of procalcitonin assays and procalcitonin-guided protocols for the management of patients with infections and sepsis. Expert Rev Mol Diagn. 2017;17(6):593-601. https://doi.org/10.1080/147371 59.2017.1324299 PMid:28443360

14. McCann FJ, Chapman SJ, Yu WC, Maskell NA, Davies RJ, Lee YC. Ability of procalcitonin to discriminate infection from non-infective inflammation using two pleural disease settings.
PLoS One. 2012;7(12):e49894. https://doi.org/10.1371/journal. pone.0049894

PMid:23251353

15. Schuetz P, Amin DN, Greenwald JL. Role of procalcitonin in managing adult patients with respiratory tract infections. Chest. 2012;141(4):1063-73. https://doi.org/10.1378/ chest.11-2430

PMid:22474148

16. Gendrel D, Raymond J, Assicot M, Moulin F, Iniguez J, Lebon P, et al. Measurement of procalcitonin levels in children with bacterial or viral meningitis. Clin Infect Dis. 1997;24(6):1240-2. https://doi.org/10.1086/513633 PMid:9195090

17. Schwarz S, Bertram M, Schwab S, Andrassy K, Hacke W Serum procalcitonin levels in bacterial and abacterial meningitis. Crit Care Med. 2000;28(6):1828-32. https://doi. org/10.1097/00003246-200006000-00024 PMid: 10890628

18. Jereb M, Muzlovic I, Hojker S, Strle F. Predictive value of serum and cerebrospinal fluid procalcitonin levels for the diagnosis of bacterial meningitis. Infection. 2001;29(4):209-12. https://doi. org/10.1007/s15010-001-1165-z

PMid:11545482

19. Wei TT, Hu ZD, Qin BD, Ma N, Tang QQ, Wang LL, et al. Diagnostic accuracy of procalcitonin in bacterial meningitis versus nonbacterial meningitis: A systematic review and metaanalysis. Medicine (Baltimore). 2016;95(11):e3079. https://doi. org $/ 10.1097 / \mathrm{md} .0000000000003079$

PMid:26986140

20. Sanaei Dashti A, Alizadeh S, Karimi A, Khalifeh M, Shoja SA Diagnostic value of lactate, procalcitonin, ferritin, serum-Creactive protein, and other biomarkers in bacterial and viral meningitis. Medicine (Baltimore). 2017;96(35):e7637. https:// doi.org/10.1097/md.0000000000007637 PMid:28858084

21. Viallon A, Desseigne $N$, Marjollet $O$, Birynczyk A, Belin $M$, Guyomarch S, et al. Meningitis in adult patients with a negative direct cerebrospinal fluid examination: Value of cytochemical markers for differential diagnosis. Crit Care. 2011;15(3):R136. https://doi.org/10.1186/cc10254

PMid:21645387

22. Alkholi UM, Abd Al-Monem N, Abd El-Azim AA, Sultan $\mathrm{MH}$. Serum procalcitonin in viral and bacterial meningitis. J Glob Infect Dis. 2011;3(1):14-8. https://doi.org/10.4103/0974-777x.77290 PMid:21572603

23. Viallon A, Zeni F, Lambert C, Pozzetto B, Tardy B, Venet C, et al High sensitivity and specificity of serum procalcitonin levels in adults with bacterial meningitis. Clin Infect Dis. 1999;28(6):13136. https://doi.org/10.1086/514793

PMid: 10451174

24. Marková M, Brodská H, Malíčková K, Válková V, Cetkovský $P$, Kolář $\mathrm{M}$, et al. Substantially elevated C-reactive protein (CRP), together with low levels of procalcitonin (PCT), contributes to diagnosis of fungal infection in immunocompromised patients. Support Care Cancer. 2013;21(10):2733-42. https://doi. org/10.1007/s00520-013-1844-1

PMid:23712521 